\title{
Public Knowledge of Diabetes and Hypertension in Metropolitan Cities, Indonesia
}

\section{Pengetahuan Masyarakat Tentang Diabetes dan Hipertensi di Kota Metropolitan, Indonesia}

\author{
I Gede M.Y. Bakti ${ }^{* 1}$, Sumardjo ${ }^{2}$, Anna Fatchiya ${ }^{3}$, Agus F. Syukri ${ }^{4}$ \\ ${ }^{1,4}$ Bagian Penelitian Kebijakan dan Manajemen Iptek dan Inovasi, Lembaga Ilmu Pengetahuan Indonesia, Jakarta \\ ${ }^{1,2,3}$ Bagian Sains Komunikasi dan Pengembangan Masyarakat, Institut Pertanian Bogor, Bogor
}

DOI: 10.24252/al-sihah.v13i1.19409

Received: 10 February 2021 / In Reviewed: 18 May 2021 / Accepted: 26 June 2021 / Available online: 30 June 2021

(C) The Authors 2021. This is an open access article under the CC BY-NC-SA 4.0 license

\begin{abstract}
Non-communicable diseases (NCDs), such as diabetes and hypertension, contributed significantly to the mortality rate in Indonesia. Citizens' unhealthy behaviors have led to an increased risk of diabetes and hypertension. This study aimed to investigate the level of public knowledge regarding diabetes and hypertension. Data were collected through a survey using questionnaires. There were 307 respondents from Medan $(n=190)$ and Jakarta $(n=118)$. The sample was dominated by the female $(68,5 \%)$ and high school graduates $(76.3 \%)$. The data revealed that 2.3 percent of the respondents suffered or are currently suffering from diabetes and 3.6 percent of the respondents suffered or are currently suffering from hypertension. The results showed that the level of public knowledge regarding diabetes (65.91\%) and hypertension (58.15\%) was not ideal in general. Many citizens still did not understand various aspects of diabetes and hypertension, such as the causes, consequences, treatments, and characteristics of their sufferer. This study also found that there are group differences in the level of public knowledge based on gender and geographical location.
\end{abstract}

\section{ABSTRAK}

Penyakit tidak menular (PTM), seperti diabetes dan hipertensi, berkontribusi secara signifikan terhadap tingkat mortalitas di Indonesia. Perilaku masyarakat yang tidak sehat telah menyebabkan peningkatan risiko diabetes dan hipertensi. Penelitian ini bertujuan untuk mengetahui tingkat pengetahuan masyarakat tentang diabetes dan hipertensi. Pengumpulan data dilakukan melalui survei dengan menggunakan kuesioner. Terdapat 308 responden berasal dari Medan $(\mathrm{n}=190)$ dan Jakarta $(\mathrm{n}=118)$. Sampel penelitian didominasi oleh perempuan (68,5\%) dan lulusan Sekolah Menengah Tingkat Atas (SMTA) (76,3\%). Data juga menunjukkan bahwa 2,3 persen responden pernah atau sedang menderita diabetes dan 3,6 persen responden pernah atau sedang menderita hipertensi. Hasil penelitian menunjukkan bahwa secara umum tingkat pengetahuan masyarakat tentang diabetes $(65,91 \%)$ dan hipertensi $(58,15 \%)$ belum ideal. Banyak masyarakat yang masih belum memahami berbagai aspek diabetes dan hipertensi, seperti penyebabnya, akibatnya, cara penanganannya, dan karakteristik dari penderita diabetes dan hipertensi. Penelitian ini juga menemukan bahwa terdapat perbedaan kelompok pengetahuan masyarakat berdasarkan jenis kelamin dan tempat tinggal.

\section{GRAPHICAL ABSTRACT}

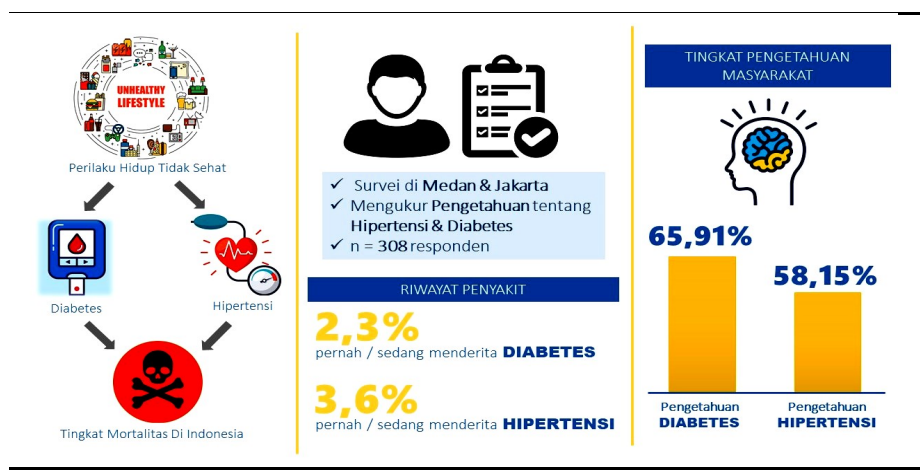

Keyword

community health; diabetes; health knowledge; hypertension; non-communicable diseases

\section{Kata Kunci:}

diabetes; hipertensi; kesehatan masyarakat; pengetahuan kesehatan; penyakit tidak menular

\section{* Correspondence}

Perumahan KORPRI Blok G2 No.2, Suradita,

Cisauk, Kab. Tangerang, Banten, 15343

Email: gede_tok@yahoo.co.id 


\section{PENDAHULUAN}

Saat ini masyarakat dunia sedang mengalami double burden diseases, yaitu keadaan ketika penyakit tidak menular (PTM) terus bertambah, namun penyakit menular juga masih belum diberantas (Kalsum, 2019). Menurut Organisasi Kesehatan Dunia setiap tahun 41 juta orang meninggal karena PTM dan jumlah tersebut setara dengan 71 persen dari semua kematian di dunia (World Health Organization [WHO], 2018). Jika kondisi tersebut tidak ditangani dengan baik, kematian yang diakibatkan oleh PTM diperkirakan akan terus mengalami peningkatan (Trisnowati, 2018). PTM yang berkontribusi besar terhadap tingkat kematian secara global adalah diabetes (WHO, 2016) dan hipertensi (Danaei et al., 2011). Di Indonesia, diabetes dan hipertensi termasuk dalam kelompok penyakit utama yang menyebabkan kematian (Kementerian Kesehatan [Kemenkes], 2019).

Diabetes dan hipertensi merupakan penyakit berbahaya bagi masyarakat Indonesia (Kemenkes, 2019). Sayangnya, selama ini masih banyak masyarakat Indonesia masih melakukan berbagai perilaku tidak sehat yang meningkatkan risiko terkena diabetes dan hipertensi. Perilaku tidak sehat tersebut, antara lain (1) rendahnya konsumsi buah dan sayur (Hermina \& Prihatini, 2016), (2) tingginya konsumsi makanan dan minuman cepat saji dengan tinggi lemak dan rendah serat (Rahmawati \& handayani, 2014), (3) banyaknya perilaku merokok dan minum beralkohol (Kemenkes, 2019), (4) kurangnya aktivitas fisik (Kemenkes, 2019), (5) banyaknya masyarakat dengan berat ba- dan lebih (overweight) dan obesitas (Kemenkes, 2019). Jika perilaku tersebut tidak diubah menjadi perilaku sehat maka hal tersebut akan berdampak pada semakin banyak masyarakat menderita PTM, khususnya diabetes dan hipertensi (Slavin \& Lloyd, 2012; Kar \& Khandelwal, 2015; Cullmann et al., 2012; Virdis et al., 2010; Colberg et al., 2016). Penambahan jumlah penyakit tersebut juga akan menimbulkan banyak kerugian seperti tingkat kemiskinan bertambah, biaya kesehatan negara bertambah, biaya rumah tangga bertambah, dan kehilangan pekerjaan lebih besar (WHO, 2018).

Salah satu faktor penentu perilaku kesehatan adalah pengetahuan kesehatan (Huo et al., 2018). Ini artinya perilaku masyarakat yang tidak sehat disebabkan oleh pengetahuan kesehatan mereka yang rendah. Hal tersebut dapat terjadi karena kurangnya pengetahuan mereka terhadap risiko dan manfaat dari perilaku sehat membuat mereka tidak termotivasi untuk mengubah kebiasaannya yang tidak sehat menjadi perilaku sehat (Huo et al., 2018). Secara umum, pengetahuan kesehatan dapat didefinisikan sebagai pengetahuan spesifik tentang kesehatan dan perawatan kesehatan baik dari aspek konten dan konteks (Gellert et al., 2016). Lebih spesifik, pengetahuan kesehatan dapat mencakup tentang pemahaman terhadap segala informasi faktual tentang kesehatan serta mengetahui bagaimana dan kapan menerapkan informasi faktual tersebut (Gellert et al., 2016). Dalam perkembangannya, berbagai peneliti telah mempelajari pengetahuan kesehatan di berbagai domain kesehatan, seperti nutrisi 
(Dickson-Spillmann, 2011), pangan sehat (Zarnowiecki et al., 2012), kanker (Viswanath et al., 2006), ginjal kronis (Wright et al., 2011), diabetes (Mufunda et al., 2012), dan hipertensi (Oliveria et al., 2005). Mengacu pada definisi Gellert et al. (2016), pengetahuan kesehatan diabetes dan hipertensi adalah pemahaman individu terhadap informasi faktual seputar diabetes dan hipertensi, serta mengetahui bagaimana dan kapan menerapkannya.

Untuk mengurangi penderita diabetes dan hipertensi, pemerintah Indonesia sebenarnya sudah melakukan berbagai upaya, contohnya program nasional Germas (Gerakan Masyarakat Hidup Sehat) (Kementerian PPN, 2017). Meskipun begitu, kenyataannya jumlah PTM di Indonesia tetap mengalami peningkatan pada tahun 2018 (Kemenkes, 2019). Kondisi tersebut juga berlaku di kota metropolitan Indonesia, yaitu Medan dan Jakarta. Berdasarkan kondisi tersebut, penting dilakukan penelitian untuk mengetahui tingkat pengetahuan masyarakat Jakarta dan Medan terkait dengan diabetes dan hipertensi. Hal ini mengingat beberapa penelitian sebelumnya menunjukkan bahwa pengetahuan kesehatan juga dipengaruhi oleh karakteristik masyarakat (Beier \& Ackerman, 2003; Al-Ansari \& Honkala, 2007; Al-Sarihin et al., 2012). Oleh karena itu, penelitian ini juga bertujuan untuk menganalisis tingkat pengetahuan kesehatan tentang diabetes dan hipertensi di Kota Medan dan Jakarta.

\section{METODE PENELITIAN}

Penelitian ini dilakukan dengan pendekatan kuantitatif. Lebih spesifik, penelitian deskriptif dan uii perbedaan digunakan pada penelitian ini. Dalam pengumpulan data, penelitian ini menggunakan survei dengan kuesioner. Survei ini dilakukan di dua lokasi, yaitu Jakarta dan Medan. Terdapat beberapa pertimbangan lokasi tersebut dijadikan sebagai objek penelitian ini. Pertama, Jakarta dan Medan merupakan wilayah dengan jumlah penduduk besar di Indonesia. Menurut data BPS, jumlah penduduk Jakarta adalah 9.588.198 jiwa dan Medan adalah 2.109.339 jiwa (Badan Pusat Statistik Indonesia, 2010). Kedua, Jakarta dan Medan memiliki karakteristik masyarakat yang heterogen (Siregar, 2017; Hidayat et al., 2012). Ketiga, wilayah tersebut juga berkontribusi terhadap jumlah diabetes dan hipertensi di Indonesia (Kemenkes, 2019).

Responden dalam penelitian ini sebanyak 308 orang dengan 190 responden berasal dari Medan dan 118 responden berasal dari Jakarta. Responden tersebut diperoleh berdasarkan teknik purposive sampling dengan kriteria masyarakat dewasa yang berumur 17 tahun ke atas. Adapun, lokasi pengambilan data dipilih secara acak dari level kecamatan sampai dengan kelurahan. Setelah lokasi survei diperoleh, pengambilan data dilakukan dengan mengunjungi rumah-rumah untuk mencari responden yang memenuhi kriteria penelitian ini.

Kuesioner penelitian ini dibagi menjadi dua bagian. Bagian pertama adalah bagian kuesioner yang menanyakan karakteristik responden, seperti jenis kelamin, usia, tingkat pendidikan, tingkat penghasilan setiap bulan, dan perilaku sehat, seperti 
Tabel 1

Karakteristik Responden

\begin{tabular}{lll}
\hline Kriteria & Kategori & Persentase (\%) \\
\hline Jenis Kelamin & Pria & 31,5 \\
& Wanita & 68,5 \\
Usia & $\leq 20$ tahun & \\
& $21-30$ tahun & 14,9 \\
& $31-40$ tahun & 28,2 \\
& $41-50$ tahun & 21,1 \\
& $\geq 51$ tahun & 25,6 \\
& & 10,1 \\
Pendidikan Formal & Tidak Sekolah / Tidak Lulus Sekolah Dasar & 0 \\
& Lulus Sekolah Dasar (SD) & 3,9 \\
& Lulus Sekolah Menengah Tingkat Pertama (SMTP) & 10,4 \\
& Lulus Sekolah Menengah Tingkat Atas (SMTA) & 76,3 \\
Penghasilan Setiap Bulan & Lulus Universitas (D3, D4, S1, S2 / S3) & 9,4 \\
& & \\
& Rpp2.500.000 & 52,9 \\
Pengalaman Merokok & Rp2.500.001 - Rp5.000.000 & 39,0 \\
& $>$ Rp5.000.000 & 8,1 \\
& & \\
& Masih merokok (perokok) & 15,3 \\
Pengalaman Minum Alkohol & Telah berhenti merokok & 82,1 \\
& Tidak pernah merokok & 2,6 \\
& Masih meminum alkohol & 1,3 \\
& Telah berhenti meminum alkohol & 2,3 \\
& Tidak pernah meminum alkohol & 96,4 \\
& & 2,3 \\
& Pernah / sedang mengidap diabetes & 97,7 \\
& Tidak pernah & 3,6 \\
& Pernah / sedang mengidap hipertensi & 96,4 \\
\hline \multirow{3}{*}{ Riwayat Diabetes } & Tidak pernah &
\end{tabular}

pengalaman merokok, pengalaman minum alkohol, riwayat diabetes dan hipertensi. Sementara itu, bagian kedua adalah bagian yang menanyakan tentang pengetahuan diabetes dan hipertensi. Mengacu pada studi Yaghmale, untuk memenuhi validitas isi, pengukuran suatu variabel dapat mengacu pada penelitian terdahulu yang telah terbukti validitasnya (Yaghmale, 2003). Pada penelitian ini pengukuran pengetahuan diabetes dan hipertensi diadaptasi dari studi Gazmararian dkk. yang sama-sama mengukur pengetahuan diabetes dan hipertensi untuk konteks penderita penyakit kronis di Amerika Serikat (Gazmararian et al., 2003). Lebih spesifik, pengetahuan diabetes diukur dengan 12 indikator pertanyaan dan pengetahuan hipertensi diukur dengan 11 indikator pertanyaan. Item indikator pengukuran tersebut dapat dilihat pada tabel 2 untuk pengetahuan diabetes dan tabel 3 untuk pengetahuan hipertensi.

Penelitian ini menggunakan analisis statistik deskriptif untuk mengetahui proporsi jawaban yang benar dari setiap pertanyaan tentang pengetahuan diabetes dan 
hipertensi. Hasil penilaian dikonversi menjadi nilai dengan skala $0-100$. Pada penelitian ini, pengetahuan dikatakan ideal ketika hasil analisis menunjukkan skor pengetahuan berada pada level $>80$ (Harsono et al., 2018; Rifsyina \& Briawan, 2015). Selain itu, analisis t-test atau analysis of variance (ANOVA) digunakan untuk mengetahui perbedaan pengetahuan diabetes dan hipertensi berdasarkan karakteristik responden, seperti jenis kelamin, usia, tingkat pendidikan, tingkat penghasilan, dan tempat tinggal. Hasil analisis tersebut menunjukkan adanya perbedaan tingkat pengetahuan ketika hasil analisis mendapatkan nilai probabilitas ( $p$-value) lebih kecil dari nilai alpha, yaitu 0.05 (Malhotra \& Birks, 2007).

\section{HASIL PENELITIAN}

\section{Karakteristik Responden}

Tabel 1 menunjukkan gambaran karakteristik responden penelitian ini. Dari tabel tersebut dapat dilihat bahwa responden didominasi dari kalangan perempuan (68,5\%) dan lulusan Sekolah Menengah Tingkat Atas (SMTA) (76,3\%). Berdasarkan tingkat penghasilan per bulan, penelitian ini menunjukkan bahwa sebagian besar responden berada pada tingkat penghasilan di bawah Rp. 2.500.000,00 $(52,9 \%)$. Kaitannya dengan perilaku sehat, penelitian ini menemukan bahwa hampir semua responden pernah memiliki pengalaman merokok $(97,4 \%)$. Di sisi lain, responden yang memiliki pengalaman minuman alkohol hanya sebanyak 11 responden $(3,6 \%)$. Adapun kaitannya dengan pengalaman diabetes dan hipertensi, penelitian ini menunjukkan bahwa hanya 7 responden pernah atau sedang mengidap diabetes $(2,3 \%)$ dan 11 responden pernah atau sedang mengidap hipertensi $(3,6 \%)$.

\section{Pengetahuan Masyarakat Terhadap Dia- betes}

Pengetahuan masyarakat tentang diabetes secara umum masih kurang. Hal ini dikarenakan total skor rata-rata pengetahuan tentang diabetes masih sebesar 65,91 persen. Proporsi jawaban benar dan salah untuk setiap pertanyaan tentang diabetes dapat dilihat pada tabel 2. Dari tabel tersebut dapat diketahui bahwa telah banyak masyarakat mengetahui level gula darah normal seseorang (92,86\%). Responden juga telah mengetahui kegunaan insulin bagi penderita diabetes $(89,61 \%)$ dan ciri-ciri penderita diabetes sedang tinggi gula darahnya adalah penderita tersebut sedang merasa haus, lelah, dan lemah (88,64\%). Responden juga mengetahui bahwa orang kurus dapat terkena diabetes $(82,79 \%)$.

Meskipun beberapa hal pengetahuan diabetes telah banyak diketahui oleh masyarakat, hasil penelitian ini menunjukkan bahwa masih banyak hal lain yang belum diketahui masyarakat terkait dengan diabetes. Berdasarkan hasil penelitian ini, pengetahuan yang belum diketahui oleh responden adalah ketika seseorang sedang merasa gemetar, berkeringat, dan lapar, itu biasanya menunjukkan gula darahnya sedang rendah, bukan sebaliknya $(82,47 \%)$. Ini artinya mereka masih belum mengenali dengan baik ciri-ciri gula darahnya sedang naik atau turun. Lebih lanjut, banyak 
Tabel 2

Proporsi Jawaban terhadap Pertanyaan Tentang Pengetahuan Diabetes

\begin{tabular}{|c|c|c|c|}
\hline \multirow[t]{2}{*}{ No } & \multirow[t]{2}{*}{ Indikator Pertanyaan } & \multicolumn{2}{|c|}{ Proporsi Jawaban } \\
\hline & & Benar $(\%)$ & Salah \% \\
\hline 1 & Gula darah normal seseorang adalah antara 70 dan $140(\mathrm{~T})$ & 92,86 & 7,14 \\
\hline 2 & $\begin{array}{l}\text { Jika orang yang terkana diabetes merasa haus, lelah, dan } \\
\text { lemah, itu berarti gula darahnya sedang tinggi }(\mathrm{T})\end{array}$ & 88,64 & 11,36 \\
\hline 3 & $\begin{array}{l}\text { Saat orang yang terkana diabetes berolahraga, gula darahnya } \\
\text { tidak akan turun }(F)\end{array}$ & 56,17 & 43,83 \\
\hline 4 & $\begin{array}{l}\text { Cara untuk menurunkan gula darah adalah dengan diberikan } \\
\text { Insulin }(T)\end{array}$ & 89,61 & 10,39 \\
\hline 5 & $\begin{array}{l}\text { Jika orang yang terkana diabetes merasa gemetar, berkeringat, } \\
\text { dan lapar, itu biasanya berarti gula darahnya tinggi }(\mathrm{F})\end{array}$ & 17,53 & 82,47 \\
\hline 6 & Diabetes dapat melukai ginjal $(\mathrm{T})$ & 78,57 & 21,43 \\
\hline 7 & Diabetes tidak dapat melukai melukai saraf (F) & 55,84 & 44,16 \\
\hline 8 & Orang yang terkena diabetes disebabkan oleh virus $(\mathrm{F})$ & 62,34 & 37,66 \\
\hline 9 & Merokok tidak akan menyebabkan diabetes (F) & 36,04 & 63,96 \\
\hline 10 & Orang kurus dapat terkena penyakit diabetes $(\mathrm{T})$ & 82,79 & 17,21 \\
\hline 11 & $\begin{array}{l}\text { Penyakit diabetes hanya dialami oleh orang dewasa dan orang } \\
\text { tua (F) }\end{array}$ & 52,92 & 47,08 \\
\hline 12 & Penyakit diabetes tidak akan menulari orang lain $(\mathrm{T})$ & 77,60 & 22,40 \\
\hline & Rerata (Mean) & 65,91 & 34,09 \\
\hline
\end{tabular}

Note: $\mathrm{T}=$ pernyataan tersebut adalah benar $($ true $) ; \mathrm{F}=$ pernyataan tersebut adalah salah (false)

masyarakat juga tidak mengetahui bahwa gula darah dapat diturunkan dengan berolahraga $(43,83 \%)$. Mengenai penyebab diabetes, hasil penelitian ini menunjukkan bahwa masih banyak masyarakat yang mengira jika diabetes disebabkan oleh virus $(37,66 \%)$. Selain itu, responden juga meyakini bahwa perbuatan merokok tidak akan menyebabkan diabetes $(63,96 \%)$. Adapun. pada penelitian ini responden yang masih merokok adalah sebanyak 15,3 persen. Sementara itu, mereka juga tidak mengetahui bahwa salah satu risiko yang akan diterima oleh penderita diabetes adalah sarafnya dapat terluka (44,16\%). Dengan kata lain, masih banyak masyarakat tidak mengetahui bahwa diabetes dapat mengakibatkan stroke. Di sisi lain, penelitian ini juga menunjukkan bahwa masih banyak yang mengira kalau diabetes hanya dialami oleh orang dewasa dan orang tua $(47,08 \%)$.

\section{Pengetahuan Masyarakat Terhadap Hipertensi}

Pengetahuan masyarakat tentang hipertensi secara umum juga belum ideal. Hal ini dikarenakan total skor rata-rata pengetahuan tentang hipertensi hanya sebesar 58,15 \%. Proporsi jawaban benar dan salah untuk setiap pertanyaan tentang hipertensi dapat dilihat pada Tabel 3. Dari tabel tersebut dapat dilihat bahwa hanya 2 item yang telah banyak diketahui masyarakat, yaitu: (1) tekanan darah tinggi yang dapat menyebabkan stroke $(87,01 \%)$, dan (2) kurang tidur dapat menyebabkan hipertensi $(84,09 \%)$.

Hasil penelitian ini menunjukkan 
Tabel 3

Proporsi Jawaban terhadap Pertanyaan Tentang Pengetahuan Hipertensi

\begin{tabular}{|c|c|c|c|}
\hline \multirow[t]{2}{*}{ No } & \multirow[t]{2}{*}{ Indikator Pertanyaan } & \multicolumn{2}{|c|}{ Proporsi Jawaban } \\
\hline & & Benar $(\%)$ & Salah $(\%)$ \\
\hline 1 & Tekanan darah pada level 80/130 adalah normal (T) & 68,18 & 31,82 \\
\hline 2 & $\begin{array}{l}\text { Tekanan darah pada level 100/160 adalah masih tergolong } \\
\text { normal (F) }\end{array}$ & 50,00 & 50,00 \\
\hline 3 & $\begin{array}{l}\text { Jika Orang tua terkena hipertensi maka anakanya tertular pen- } \\
\text { yakit hipertensi juga (F) }\end{array}$ & 44,16 & 55,84 \\
\hline 4 & $\begin{array}{l}\text { Tekanan darah tinggi tidak akan menyebabkan serangan jan- } \\
\text { tung (F) }\end{array}$ & 55,84 & 44,16 \\
\hline 5 & Tekanan darah tinggi dapat menyebabkan penyakit kanker $(F)$ & 54,87 & 45,13 \\
\hline 6 & Tekanan darah tinggi dapat menyebabkan penyakit stroke $(\mathrm{T})$ & 87,01 & 12,99 \\
\hline 7 & $\begin{array}{l}\text { Hipertensi yang sudah tinggi tidak akan turun meski sudah } \\
\text { berolah raga setiap hari }(\mathrm{F})\end{array}$ & 48,70 & 51,30 \\
\hline 8 & $\begin{array}{l}\text { Tekanan darah yang sudah tinggi dapat diturunkan dengan } \\
\text { mengurangi berat badan }(T)\end{array}$ & 75,65 & 24,35 \\
\hline 9 & $\begin{array}{l}\text { Tekanan darah tinggi sering terjadi pada indeks massa tubuh } \\
20-25 \mathrm{~kg} / \mathrm{m}^{2} \text { (F) }\end{array}$ & 38,96 & 61,04 \\
\hline 10 & Hipertensi terjadi karena tubuh kekurangan natrium $(\mathrm{F})$ & 32,14 & 67,86 \\
\hline 11 & Kurang tidur dapat menyebabkan hipertensi (T) & 84,09 & 15,91 \\
\hline & $\begin{array}{c}\text { Rerata (Mean) } \\
\end{array}$ & 58,15 & 41,85 \\
\hline
\end{tabular}

Note: $\mathrm{T}=$ pernyataan tersebut adalah benar $($ true $) ; \mathrm{F}=$ pernyataan tersebut adalah salah (false)

bahwa masih banyak hal lain yang belum diketahui masyarakat terkait dengan hipertensi. Masih banyak dari mereka yang meyakini bahwa tekanan darah pada level $100 / 160$ adalah normal (50,00\%). Ini dapat menunjukkan bahwa masih banyak masyarakat yang tidak mengetahui batas tekanan darah rendah, normal dan tinggi. Sebanyak 55,84\% juga tidak mengetahui bahwa penderita hipertensi tidak akan menulari anaknya secara langsung. Dengan kata lain, banyak masyarakat yang meyakini bahwa hipertensi adalah penyakit menular. Penelitian ini juga menunjukkan bahwa masih banyak masyarakat tidak mengetahui penyebab dari hipertensi adalah (1) kebanyakan mengonsumsi natrium $(67,86 \%)$ dan indeks masa tubuh yang tinggi (obesitas) (61,04\%). Terkait dengan penanganannya, ternyata banyak responden juga tidak mengetahui bahwa berolah raga setiap hari dapat menurunkan hipertensi (51,30\%). Sementara itu, masih banyak dari responden yang tidak mengetahui bahwa dapat menyebabkan kanker $(45,13 \%)$ dan tidak akan menyebabkan serangan jantung $(44,16 \%)$

\section{Pengetahuan Diabetes dan Hipertensi Berdasarkan Karakteristik Responden}

Tabel 4 menunjukkan tingkat pengetahuan diabetes dan hipertensi berdasarkan karakteristik profil. Berdasarkan hasil penelitian ini, laki-laki dan perempuan memiliki perbedaan yang signifikan mengenai pengetahuan diabetes $\left(\overline{\mathrm{X}}_{\text {pria }}=\right.$ $68,81, \overline{\mathrm{X}}_{\text {wanita }}=64,57$; -value $\left.\leq 0,05\right)$. Hasil penelitian ini menunjukkan bahwa laki-laki memiliki pengetahuan diabetes yang lebih baik dari pada perempuan. Meskipun be- 


\section{Tabel 4}

Pengetahuan Diabetes dan Hipertensi

\begin{tabular}{|c|c|c|c|c|c|c|}
\hline \multirow[t]{2}{*}{ Karakteristik Responden } & \multicolumn{3}{|c|}{ Diabetes } & \multicolumn{3}{|c|}{ Hipertensi } \\
\hline & $M$ & $S D$ & $p$-value & $M$ & $S D$ & $p$-value \\
\hline Jenis Kelamin & & & 0,016 & & & 0,871 \\
\hline Laki-laki & 68,81 & 13,67 & & 58,39 & 17,25 & \\
\hline Perempuan & 64,57 & 14,61 & & 58,03 & 17,90 & \\
\hline Usia & & & 0,269 & & & 0,606 \\
\hline$\leq 20$ th & 65,04 & 13,57 & & 57,12 & 16,67 & \\
\hline $21-30$ th & 66,76 & 13,48 & & 58,31 & 16,26 & \\
\hline $31-40$ th & 66,15 & 13,89 & & 55,80 & 17,96 & \\
\hline $41-50$ th & 63,61 & 15,46 & & 59,15 & 18,81 & \\
\hline$\geq 51$ th & 70,16 & 16,35 & & 61,58 & 19,60 & \\
\hline Pendidikan Formal & & & 0,474 & & & 0,340 \\
\hline SMTP kebawah & 67,42 & 14,80 & & 59,09 & 20,80 & \\
\hline SMTA & 65,35 & 14,30 & & 57,45 & 17,42 & \\
\hline Universitas & 68,10 & 15,12 & & 62,38 & 14,11 & \\
\hline Penghasilan Per Bulan & & & 0,229 & & & 0,086 \\
\hline$\leq \mathrm{Rp} 2.500 .000$ & 65,49 & 14,25 & & 56,61 & 16,49 & \\
\hline $\begin{array}{l}\text { Rp2.500.001 - } \\
\text { Rp5.000.000 }\end{array}$ & 65,49 & 15,02 & & 58,86 & 18,97 & \\
\hline$>$ Rp5.000.000 & 70,67 & 12,29 & & 64,73 & 17,67 & \\
\hline Kota & & & 0,000 & & & 0,000 \\
\hline Medan & 70,39 & 14,93 & & 63,26 & 16,88 & \\
\hline Jakarta & 58,69 & 10,07 & & 49,92 & 15,76 & \\
\hline
\end{tabular}

Note: $\mathrm{M}=$ rerata (mean); $\mathrm{SD}=$ standar deviasi; $p$-value $=$ nilai probabilitas

gitu, skor pengetahuan keduanya masih belum ideal. Dari sisi pengetahuan hipertensi, hasil penelitian ini menunjukkan bahwa tidak ada perbedaan yang signifikan antar lakilaki dan perempuan $\left(\overline{\mathrm{X}}_{\text {pria }}=58,39, \overline{\mathrm{X}}_{\text {wanita }}=\right.$ 58,03; $p$-value $>0,05)$. Dari tabel tersebut terlihat bahwa skor pengetahuan hipertensi keduanya juga masih belum ideal.

Hasil penelitian ini juga menunjukkan bahwa faktor usia juga tidak mempengaruhi secara signifikan skor pengetahuan responden terkait dengan diabetes $\left(\overline{\mathrm{X}}_{\leq 20 \mathrm{th}}=65,04, \overline{\mathrm{X}}_{21-30 \mathrm{th}}=66,76, \overline{\mathrm{X}}_{31-}\right.$ 40th $=66,15, \bar{X}_{41-50 \mathrm{th}}=63,61, \overline{\mathrm{X}}_{\geq 51 \mathrm{th}}=70,16 ; p$ value $>0,05)$ dan hipertensi $\left(\overline{\mathrm{X}}_{\leq 20 \mathrm{th}}=57,12\right.$, $\overline{\mathrm{X}}_{21-30 \mathrm{th}}=58,31, \quad \overline{\mathrm{X}}_{31-40 \mathrm{th}}=55,80, \overline{\mathrm{X}}_{41-50 \mathrm{th}}=$ $59,15, \quad \bar{X}_{\geq 51 \mathrm{th}}=61,58 ;$-value $\left.>0,05\right)$.
Dengan kata lain, temuan ini membuktikan bahwa di setiap usia tingkat pengetahuan diabetes dan hipertensi cenderung sama.

Pada aspek tingkat pendidikan formal, penelitian ini menemukan bahwa tidak ada perbedaan yang signifikan terhadap pengetahuan diabetes $\left(\bar{X}_{\text {SMTP_ke bawah }}=67,42\right.$, $\overline{\mathrm{X}}_{\mathrm{SMTA}}=65,35, \overline{\mathrm{X}}_{\text {Universitas }}=68,10 ;$ p-value $>$ $0,05)$ dan hipertensi $\left(\bar{X}_{\text {SMTP ke bawah }}=59,09\right.$, $\overline{\mathrm{X}}_{\mathrm{SMTA}}=57,45, \overline{\mathrm{X}}_{\text {Universitas }}=62,38$; p-value $>$ $0,05)$. Dengan demikian, temuan ini membuktikan bahwa semakin tinggi tingkat pendidikan seseorang belum tentu semakin tinggi pula pengetahuan mereka tentang diabetes dan hipertensi. Dari tabel 4 dapat dilihat bahwa tingkat pendidikan dari semua level sama-sama memiliki pengetahuan 
yang belum ideal.

Hasil serupa juga terjadi pada tingkat penghasilan. Penelitian ini menemukan bahwa tingkat penghasilan tidak mempengaruhi tingkat pengetahuan diabetes dan hipertensi. Hal ini dikarenakan tidak ada perbedaan yang signifikan untuk setiap kelompok penghasilan, baik pada pengetahuan diabetes $\left(\overline{\mathrm{X}}_{\leq \mathrm{Rp} 2.500 .000}=65,49\right.$, $\overline{\mathrm{X}}_{\mathrm{Rp2} 2.500 .001-\mathrm{Rp} 5.000 .000}=65,49, \quad \overline{\mathrm{X}}_{>\mathrm{Rp} 5.000 .000}=$ $70,67 ; p$-value $>0,05)$ dan hipertensi $\left(\overline{\mathrm{X}}_{\leq \mathrm{Rp} 2.500 .000}=56,61, \quad \overline{\mathrm{X}}_{\mathrm{Rp} 2.500 .001-\mathrm{Rp} 5.000 .000}=\right.$ $58,86, \overline{\mathrm{X}}_{>\mathrm{Rp} 5.000 .000}=64,73 ;$ p-value $\left.>0,05\right)$. Dengan demikian, hasil tersebut menunjukkan bahwa mereka ternyata sama-sama masih belum mengerti banyak hal tentang diabetes dan hipertensi.

Berbeda dengan hasil sebelumnya, penelitian ini menemukan bahwa terdapat perbedaan antara masyarakat Medan dan Jakarta terkait dengan pengetahuan diabetes $\left(\overline{\mathrm{X}}_{\text {Medan }}=70,39, \overline{\mathrm{X}}_{\mathrm{Jakarta}}=58,69 ;\right.$-value $\leq 0,05)$ dan hipertensi $\left(\overline{\mathrm{X}}_{\text {Medan }}=63,26, \overline{\mathrm{X}}_{\mathrm{Ja}-}\right.$ karta $=49,92 ; p$-value $\leq 0,05)$. Tabel 4 menunjukkan bahwa pengetahuan masyarakat Jakarta lebih rendah dari pada masyarakat Medan, baik dalam hal pengetahuan diabetes maupun hipertensi. Meskipun begitu, keduanya ternyata masih memiliki pengetahuan diabetes dan hipertensi yang belum ideal.

\section{PEMBAHASAN}

Penelitian ini secara umum menemukan bahwa pengetahuan masyarakat tentang diabetes dan hipertensi masih belum ideal. Meskipun terdapat beberapa item pengetahuan yang telah banyak dimengerti oleh masyarakat, kenyataannya masih banyak item pengetahuan belum dimengerti oleh masyarakat. Masih banyak masyarakat belum mengerti tentang diabetes dan hipertensi di berbagai aspek, seperti penyebabnya, akibatnya, cara penanganannya, dan karakteristik dari penderita diabetes dan hipertensi.

Pada aspek jenis kelamin, penelitian ini menemukan bahwa secara signifikan laki-laki memiliki pengetahuan diabetes lebih tinggi dibandingkan dengan perempuan. Temuan ini sejalan dengan beberapa studi sebelumnya, seperti Gulabani et al. (2008) dan Al-Sarihin et al. (2012) yang menyatakan bahwa laki-laki cenderung memiliki pengetahuan diabetes yang lebih tinggi dibandingkan wanita. Studi AlSarihin et al. (2012) menjelaskan bahwa hal tersebut dapat terjadi mungkin karena tingkat literasi kesehatan dari kalangan perempuan lebih rendah dari pada kalangan laki-laki. Data penelitian ini juga menunjukkan bahwa pria cenderung memiliki pendidikan yang lebih tinggi dari pada pria. Disamping itu, penelitian ini juga mendukung penelitian terdahulu yang menyatakan bahwa tidak ada perbedaan usia, pendidikan, atau penghasilan pada tingkat pengetahuan diabetes (Mufunda, et al., 2012; Al-Sarihin et al., 2012) dan pengetahuan hipertensi (Kilic et al., 2016). Tidak adanya perbedaan tingkat pengetahuan tersebut dari aspek usia, pendidikan, dan penghasilan menunjukkan bahwa pengetahuan diabetes dan hipertensi masih belum ideal di semua level usia, pendidikan, dan penghasilan. Temuan ini telah memperkuat bahwa pemerintah perlu untuk melanjutkan program promosi kesehatan perilaku hidup 
sehat di semua kelompok tersebut.

Penelitian ini juga menemukan bahwa masyarakat Jakarta memiliki pengetahuan yang berbeda dengan masyarakat Medan, baik itu tentang diabetes maupun hipertensi. Lebih lanjut, penelitian ini menunjukkan bahwa masyarakat Medan memiliki pengetahuan diabetes dan hipertensi yang lebih baik dari pada masyarakat Jakarta. Temuan ini juga selaras dengan data Riset Kesehatan Dasar tahun 2018 bahwa Jakarta menduduki peringkat prevalensi diabetes tertinggi di Indonesia pada tahun 2018. Sementara itu, Medan sebagai ibu kota provinsi Sumatra Utara berada di bawah rata-rata tingkat prevalensi nasional. Hal tersebut juga terjadi pada hipertensi, Jakarta termasuk kelompok wilayah dengan tingkat prevalensi hipertensi tertinggi di Indonesia pada tahun 2018. Sementara itu, Medan masuk ke dalam kelompok wilayah dengan tingkat prevalensi hipertensi terendah pada tahun 2018 (Kemenkes, 2018). Dengan demikian, hasil penelitian ini menunjukkan bahwa ada kemungkinan tingkat prevalensi diabetes dan hipertensi yang beragam di berbagai daerah di Indonesia berkaitan erat dengan tingkat pengetahuan masyarakat terhadap diabetes dan hipertensi.

\section{KESIMPULAN}

Penelitian ini telah berkontribusi terhadap gambaran tingkat pengetahuan masyarakat Jakarta dan Medan tentang diabetes dan hipertensi. Penelitian ini menemukan bahwa secara umum pengetahuan masyarakat terhadap diabetes dan hipertensi masih belum ideal. Tingkat pengetahuan kesehatan masyarakat Jakarta dan Medan terhadap diabetes adalah sebesar 65,91 persen dan hipertensi adalah sebesar 58,15 persen. Lebih lanjut, berbagai aspek pengetahuan tentang diabetes dan hipertensi masih belum dimengerti oleh masyarakat, seperti penyebabnya, akibatnya, cara penanganannya, dan karakteristik dari penderita diabetes dan hipertensi. Selain itu, penelitian ini menemukan bahwa terdapat perbedaan pengetahuan masyarakat berdasarkan jenis kelamin dan tempat tinggal. Lebih spesifik, ditemukan bahwa laki-laki cenderung memiliki pengetahuan diabetes lebih tinggi dibandingkan dengan perempuan. Di sisi lain, masyarakat Jakarta memiliki pengetahuan yang secara signifikan lebih rendah dari pada masyarakat Medan, baik itu tentang diabetes maupun hipertensi.

Meskipun penelitian ini telah menghasilkan temuan yang menarik di bidang kesehatan masyarakat, penelitian ini masih memiliki beberapa kekurangan. Pertama, penelitian ini hanya menunjukkan gambaran pengetahuan masyarakat tentang diabetes dan hipertensi, sehingga penelitian ini tidak mampu menjelaskan faktor-faktor yang menyebabkan tingkat pengetahuan masyarakat tentang penyakit tersebut menjadi rendah. Kedua, penelitian ini dilakukan dengan pendekatan studi potong-lintang (cros-sectional study), sehingga penelitian ini hanya mampu menggambarkan tingkat pengetahuan masyarakat tentang diabetes dan hipertensi dalam waktu tertentu saja. Untuk itu, penelitian selanjutnya bisa menggunakan pendekatan studi longitudinal untuk mengetahui perkembangan pengetahuan masyarakat tentang diabetes dan 
hipertensi dari waktu ke waktu.

Berdasarkan temuan penelitian, beberapa saran yang dapat dilakukan pemerintah untuk meningkatkan pengetahuan masyarakat tentang diabetes dan hipertensi. Pertama, pemerintah harus meningkatkan promosi kesehatan tentang diabetes dan hipertensi kepada masyarakat. Pemerintah sebaiknya melakukan promosi kesehatan tersebut secara komprehensif, baik dari aspek penyebabnya, akibatnya, cara penanganannya, dan karakteristik penderita diabetes dan hipertensi. Promosi kesehatan tersebut sebaiknya dilakukan secara gencar, rutin, dan jangka panjang agar masyarakat lebih sering terpapar dengan materi kesehatan tersebut. Promosi kesehatan tersebut juga harus menggunakan pendekatan komunikasi massa dan interpersonal.

Kedua, materi promosi kesehatan tentang diabetes dan hipertensi perlu distandarisasi dengan menyesuaikan kearifan lokal masyarakatnya. Hal ini dikarenakan penelitian ini menemukan bahwa sebagian besar karakteristik masyarakat memiliki tingkat pengetahuan kesehatan yang sama, kecuali pada aspek tempat tinggal masyarakat. Standarisasi promosi kesehatan perlu dilakukan agar setiap masyarakat mendapatkan materi kesehatan yang sama tentang diabetes dan hipertensi. Sementara itu, penyesuaian kearifan lokal masyarakat diperlukan agar mereka semakin mudah menerima materi dari setiap promosi kesehatan tersebut.

\section{DAFTAR PUSTAKA}

Al-Ansari, J.M. \& Honkala, S. (2007). Gender dif- ferences in oral health knowledge and behavior of the health science college students in Kuwait. Journal of Allied Health, 36(1), 41-46. https://

pubmed.ncbi.nlm.nih.gov/17425190/

Al-Sarihin, K.K., Bani-Khaled M.H., Haddad, F.H. \& Althwabia, R.N. (2012). Diabetes Knowledge among Patients with Diabetes Mellitus at King Hussein Hospital. Journal of The Royal Medical Services, 19(1), $72-$ 77. http://www.emro.who.int/imemrf/ J Royal Med Serv/

J_Royal_Med_Serv_2012_19_1_72_77.pdf

American Diabetes Association (ADA). (2014). Diagnosis and Classification of Diabetes Mellitus. Diabetes Care, 37(1), 581 - 682. https://doi.org/10.2337/dc14-S081

Badan Pusat Statistik Indonesia. (2010). Penduduk Indonesia: Menurut Provinsi dan Kabupaten Kota - Senus Penduduk 2010. Badan Pusat Statistik.

Beier, M.E. \& Ackerman, P.L. (2003). Determinants of health knowledge: an investigation of age, gender, abilities, personality, and interests. Journal of Personality and Social Psychology. 84(2), 439-448. https://pubmed.ncbi.nlm.nih.gov/12585815/

Colberg, S.R., Sigal, R.J., Yardley, J.E., Riddle M.C., Dunstan, D.W. et al. (2016). Physical activity/exercise and diabetes: a position statement of the American Diabetes Association. Diabetes Care, 39, 2065 - 2079. https://doi.org/10.2337/dc16-1728

Cullmann, M., Hilding, A. \& Östenson, C.G. (2012). Alcohol consumption and risk of pre-diabetes and type 2 diabetes development in a Swedish population. Diabetic Medicine, 29(4), 441-452. https://doi.org/10.1111/j.14645491.2011.03450.x

Danaei, G., Finucane, M.M., Lin, J.K., Singh, G.M., Paciorek, C.J., Cowan, M.J. et al. (2011). National, regional, and global trends in systolic blood pressure since 1980: systematic analysis of health examination surveys and epidemiological studies with 786 country-years and $5 \cdot 4$ million participants. Lancet, 12(377), 568-577. https://doi.org/10.1016/S01406736(10)62036-3

Dickson-Spillmann, M., Siegrist, M. \& Keller, C. (2011). Development and validation of a 
short, consumer-oriented nutrition knowledge questionnaire. Appetite, 56(3), 617-620.

https://doi.org/10.1016/j.appet.2011.01.034

Gazmararian, J.A., Williams, M.V., Peel, J. \& Baker, D.W. (2003). Health literacy and knowledge of chronic disease. Patient Education and Counseling. 51(3), 267-275. https://doi.org/10.1016/s07383991(02)00239-2

Gellert, P., Detel, S., Ernsting, C., Oedekoven, M. \& Kuhlmey, A. (2016). Development and psychometric properties of a health knowledge test on six chronic conditions. Patient Education and Counseling. 99(12), 2034-2042. https://doi.org/10.1016/j.pec.2016.07.035

Gulabani M, John M, Isaac R. (2008). Knowledge of diabetes, its treatment and complications amongst diabetic patients in a tertiary care hospital. Indian Journal of Community Medicine, 33, 204-206. https://doi.org/10.4103/0970-0218.42068

Harsono, Widjanarko, B. \& Prabamurti, P.N. (2018). Pengaruh tingkat pengetahuan terhadap kinerja tenaga kontrak promotor kesehatan dalam pelayanan promosi kesehatan puskesmas di Kabupaten Indramayu. Jurnal Kesehatan Indra Husada, 6(1), 14 - 30. https://garuda.ristekbrin.go.id/documents/det ail $/ 856918$

Hermina \& Prihatini, S. (2016). Gambaran Konsumsi Sayur dan Buah Penduduk Indonesia dalam Konteks Gizi Seimbang: Analisis Lanjut Survei Konsumsi Makanan Individu (SKMI) 2014. Buletin Penelitian Kesehatan, 44(2), $205-218$. https://doi.org/10.22435/bpk.v44i3.5505.205 $-218$

Hidayat, Surachman, Zain, D., \& Setiawan, M. (2012). Perilaku Kepemimpinan dan Komitmen Karyawan Pengaruhnya terhadap Kepuasan Kerja dan Kinerja Karyawan (Studi pada Dinas Kependudukan dan Pencatatan Sipil Provinsi DKI Jakarta). Jurnal Aplikasi Manajemen, 10(1), 21 - 39. https://jurnaljam.ub.ac.id/index.php/jam/arti cle/view/397

Huo, C., Zhang, M. \& Ma, F. (2018). Factors influencing people's health knowledge adoption in social media: The mediating effect of trust and the moderating effect of health threat. Library Hi Tech. 36(1), 129-151. https://doi.org/10.1108/LHT-04-2017-0074

Kalsum, U., Lesmana, O. \& Pertiwi, D. R. (2019). Pola Penyakit Tidak Menular dan Faktor Risikonya pada Suku Anak Dalam di Desa Nyogan Provinsi Jambi. Media Kesehatan Masyarakat Indonesia, 15(4), 338 - 348. http://dx.doi.org/10.30597/mkmi.v15i4.7062

Kar, S. \& Khandelwal, B. (2015). Fast foods and physical inactivity are risk factors for obesity and hypertension among adolescent school children in east district of Sikkim, India. Journal of Natural Science, Biology and Medicine, 6(2), 356-359. https://doi.org/10.4103/0976-9668.160004

Kementrian Kesehatan (2019). Hasil Utama Riskesdas 2018. Retrived November 6, 2020, from

https://www.litbang.kemkes.go.id/hasilutama-riskesdas-2018/

Kementrian PPN. (2017). Peraturan Menteri PPN Nomor 17 Tahun 2017 Tentang Pedoman Umum Pelaksanaan Gerakan Masyarakat Hidup Sehat. Kementrian PPN.

Kilic, M., Uzuncakmak, T. \& Ede H. (2016). The effect of knowledge about hypertension on the control of high blood pressure. International Journal of the Cardiovascular Academy, $\quad 2(1): \quad 27 \quad-\quad 32$. https://doi.org/10.1016/j.ijcac.2016.01.003

Malhotra, N.K. \& Birks, D.F. (2007). Marketing Research: An applied Approach (3th ed.). Essesex: Pearson Education Limited.

Mufunda, E., Wikby, K., Björn, A. \& Hjelm, K. (2012). Level and determinants of diabetes knowledge in patients with diabetes in Zimbabwe: a cross-sectional study. The Pan African Medical Journal, 13, 78. https://pubmed.ncbi.nlm.nih.gov/23396799/

Oliveria, S. A., Chen, R. S., McCarthy, B. D., Davis, C. C. \& Hill, M. N. (2005). Hypertension knowledge, awareness, and attitudes in a hypertensive population. Journal of general internal medicine, 20(3), 219-225. https://doi.org/10.1111/j.15251497.2005.30353.x

Rahmawati. W. \& Handayani, D. (2014). Different recipes and Energy Density of Indonesia fast food on percentage of Indonesian daily value. Obesity \& Control Therapies, 1(2), 1-5. http://dx.doi.org/10.15226/2374- 
$8354 / 1 / 2 / 00108$

Rifsyina, N.N. \& Briawan, D. (2015). Pengetahuan, persepsi, dan penerapan diet penurunan berat badan pada mahasiswa gizi putra. Jurnal Gizi dan Pangan. 10(2), 109 - 116. https://doi.org/10.25182/jgp.2015.10.2.\%25

$\mathrm{p}$

Slavin, J. L. \& Lloyd, B. (2012). Health Benefits of Fruits and Vegetables. American Society for Nutrition. Advances in Nutrition, 3, 506516. https://doi.org/10.3945/an.112.002154

Trisnowati, H. (2018). Pemberdayaan Masyarakat untuk Pencegahan Faktor Risiko Penyakit Tidak Menular (Studi pada Pedesaan di Yogyakarta). Media Kesehatan Masyarakat Indonesia, $14(1), \quad 17-25$. http://dx.doi.org/10.30597/mkmi.v14i1.3710

Virdis, A., Giannarelli, C., Neves, M.F., Taddei, S. \& Ghiadoni, L. (2010). Cigarette smoking and hypertension. Current Pharmaceutical Design, 16(23), 2518-2525. https://doi.org/10.2174/13816121079206292 0

Viswanath, K., Breen, N., Meissner, H., Moser, R.P., Hesse, B., Steele, W.R. et al. (2006). Cancer Knowledge and Disparities in the Information Age. Journal of Health Communication: International Perspectives, 11(1), 1-17. https://doi.org/10.1080/10810730600637426

World Health Organization. (2016). Global Report on Diabetes. France: World Health Organization.

https://www.who.int/publications/i/item/978 9241565257

World Health Organization. (2018). Noncommunicable Diseases. Retrived November 6, 2020 from https://www.who.int/news-room/factsheets/detail/noncommunicable-diseases

Wright, J.A., Wallston, K.A., Elasy, T.A., Ikizler, T.A. \& Cavanaugh, K.L. (2011). Development and results of a kidney disease knowledge survey given to patients with CKD. American Journal of Kidney Diseases, 57(3), 387-395. https://doi.org/10.1053/j.ajkd.2010.09.018

Yaghmale, F. (2003). Content Validity and Its Estimation. Journal of Medical Education, 3(1), 25-27.

https://doi.org/10.22037/jme.v3i1.870

Zarnowiecki, D., Sinn, N., Petkov, J. \& Dollman, J. (2012). Parental nutrition knowledge and attitudes as predictors of 5-6-year-old children's healthy food knowledge. Public Health Nutr, 15(7), 1284-1290. https://doi.org/10.1017/S136898001100325 